\title{
Vitruvius Revisited: Palladio's Canonical Orders in the First Book of "I Quattro Libri dell'Architettura"
}

\begin{abstract}
This contribution examines Palladio's relation to Vitruvius with regard to the canonical orders: the Tuscan, Doric, Ionic and Corinthian. Palladio became acquainted with Vitruvius through his first mentor, Gian Giorgio Trissino, who had founded an academy. In the first book of I Quattro Libri dell'Architettura Palladio repeatedly refers to Vitruvius. However, like most Renaissance architects, Palladio also studied the existing remains of Roman architecture. For him, archaeological evidence had more weight than the written words of Vitruvius. Though Palladio regarded Vitruvius as his "master and guide", he would deviate from Vitruvius' rules when he found the remains of Roman architecture more satisfactory. For Palladio, Vitruvius' rules were not unalterable, they were guidelines which the architect could modify.
\end{abstract}

\section{Introduction}

When Andrea Palladio (1508-1580) published his treatise I Quattro Libri dell'Architettura in 1570, he was sixty-two years old and had long been acquainted with Vitruvius, at least since Palladio's encounter in the late 1530s with his first mentor, the Vicentine patrician and poet Gian Giorgio Trissino (1478-1550). ${ }^{1}$ An able connoisseur (his drawings for his own city palace and a brief introduction to an architectural treatise still survive), Trissino facilitated Palladio's first trip to Rome in 1541 and played a decisive role in the transformation of the humble stonemason into the architect Palladio. In addition to reading Vitruvius with the Vicentine humanist, Andrea's architectural training consisted of studying and copying the drawings of other architects, such as Raphael (1483-1520) and Sebastiano Serlio (14751554). It was at his villa at Cricoli, on the outskirts of Vicenza, that Trissino founded an academy, as a place to educate young Vicentine nobles along the lines of the famous humanist academies in Florence and Rome that promoted classical literature. According to

\footnotetext{
*ACKNOWLEGEMENTS: Research funded by the EURIAS Fellowship Programme, the European Commission (Marie-Sklodowska-Curie Actions - COFUND Programme - FP 7) and the Collegium Helveticum.

${ }^{1}$ However, Palladio may have known Gian Giorgio Trissino from 1531. On Gian Giorgio Trissino, see Morsolin 1894.
} 
Palladio's biographer, Paolo Gualdo (1553-1621), Andrea also benefited from Trissino's Academy: "finding Palladio to be a young man of very spirited character and with a great aptitude for science and mathematics, Trissino encouraged his natural abilities by training him in the precepts of Vitruvius". ${ }^{2}$ Giangiorgio Zorzi lists eight of Palladio's drawings in connection with his early Vitruvian studies, now preserved at the Royal Institute of British Architects Library Drawings and Archives Collections. ${ }^{3}$

Later in his career, Palladio contributed substantially to the 1556 and 1567 Italian and Latin editions of Vitruvius by the Venetian patrician Daniele Barbaro (1514-1570), which mark the splendid culmination of the Renaissance tradition of Vitruvian studies. ${ }^{4}$ In the preparation of the work, begun probably in 1547 and taking - according to Barbaro himself nine years to complete, he enjoyed the active collaboration of Palladio, who not only designed the most important woodcuts in books I-VI, but also contributed his own fund of archaeological experience to the interpretation of Vitruvius's text. ${ }^{5}$ In Barbaro's acknowledgement of Palladio's assistance, he specifically cites his work on the ancient Roman theatre, temples, the Roman basilica, and also on the reconstruction of the Ionic volute. $^{6}$ Equipped with Latin and Greek and with extensive classical and mathematical knowledge, Daniele Barbaro was the ideal editor of Vitruvius. ${ }^{7}$ However, he clearly lacked architectural and archaeological experience, which probably prompted the collaboration with Palladio, who in Barbaro's judgement, was designing buildings which rivaled those of classical antiquity. ${ }^{8}$ Being thus no mere illustrator, Palladio was able to provide Barbaro with architectural and archaeological insights for the commentary.

\footnotetext{
${ }^{2}$ Gualdo 1959, 93-104 (particularly 93): "Sorgendo esso Trissino il Palladio esser giovane molto spiritoso ed inclinato molto alle scienze matematiche, per coltivar questo ingegno s'indusse egli stesso ad esplicarli Vitruvio".

${ }^{3} \mathrm{RIBA}, \mathrm{XI} / 7$ recto (half-elevation of a diastylos Doric temple); RIBA XI/7 verso (Doric entablature); RIBA XI/10 recto (half-elevation of an eustylos Ionic temple) (FIG. 1); RIBA XI/9 recto (half-elevation of a systylos Ionic temple); RIBA XI/9 verso (Ionic base and capital after Vitruvius) (FIG. 2); RIBA X/4 verso (elevation of the monopteral round temple); and RIBA VIII/6 (elevation of the peripteral round temple). See Zorzi 1959, 121-123.

${ }^{4}$ For the development of Vitruvian studies during the Renaissance, see the general survey in Pagliara 1986, 3-85, and in Clarke 2002, 317-44. See also Long 1979.

${ }^{5}$ Barbaro's statement that it took nine years to complete his edition of Vitruvius should be considered, however, in connection with Horace's Ars Poetica (lines 388-9), where Horace recommends waiting nine years before publishing one's compositions. This became something of a topos among classically educated Renaissance writers, and it may well be that Barbaro is referring to the conventional time of literary "gestation" rather than giving us precise information about the dating of the work.

${ }^{6}$ Barbaro 1556, 40: "Ne i disegni delle figure importanti, ho usato l'opera di M. Andrea Palladio Vicentino Architetto, il quale ha con incredibile profitto tra quanti ho conosciuto, e di vista, e di fama, e per giudicio de uomini eccellenti acquistato la vera Architettura non solo intendendo le belle, e sottili ragioni di essa, ma anco ponendola in opera, si ne i sottilissimi, e vaghi disegni delle piante, de gli alzati, e de i profili, come ne lo eseguire e far molti e superbi Edificij nela patria sua, e altrove, che contendono con gli antichi, danno luni a moderni, e daran meraviglia a quelli che verranno. Et quanto appartiene a Vitruvio, l'artificio de i teatri, de i Tempi, de le Basiliche, e di quelle che hanno più belle, e più secrete ragioni di compartimenti, tutte sono state da quello con prontezza d'anima, e di mano esplicate e seco consigliate, come da quello che di tutta Italia con giudicio ha scelto le più belle maniere de gli antichi, e misurate tutte l'opere che si trovano".

${ }^{7}$ The bibliography on Barbaro is vast. See, for example, Cellauro 2000, 87-134; Cellauro 2004, 293-329: and the forthcoming proceedings of the 2013 conference Barbaro 500.

${ }^{8}$ Barbaro 1567, 64: “ ... Andrea Palladio ... il quale ha ... acquistato gran nome si i sottillissimi, e vaghi disegni delle piante, de gli alzati, e de i profili, come nello seguire, e fare molti e superbi 's, si nella sua patria sua come altrove e
} 


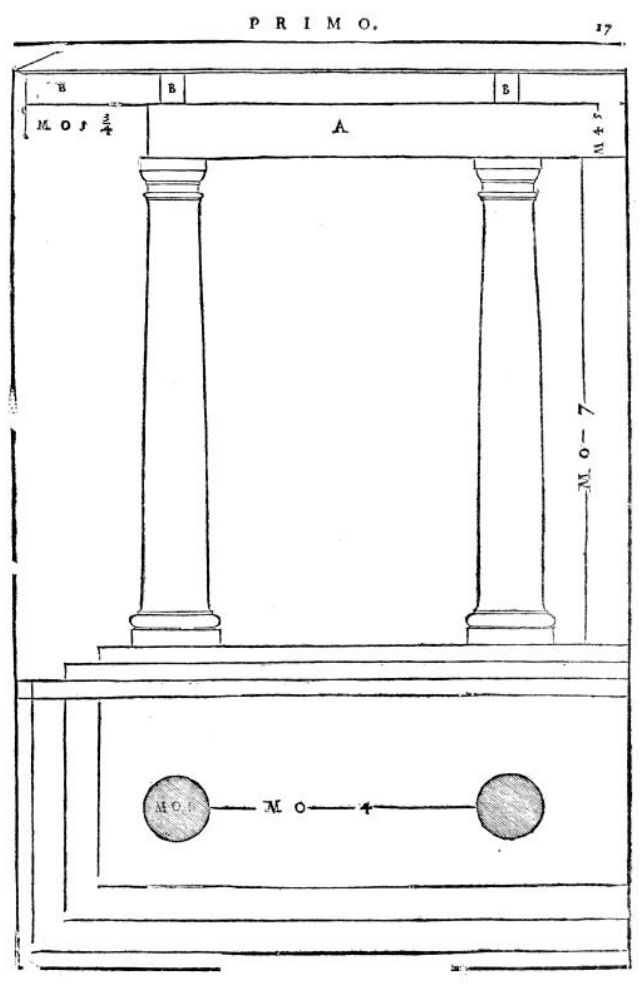

FIG. 1 - Andrea Palladio, The freestanding Tuscan order, from I Quattro Libri dell'Architettura, Venice, 1570 (Photo: Stiftung Werner Oechslin).

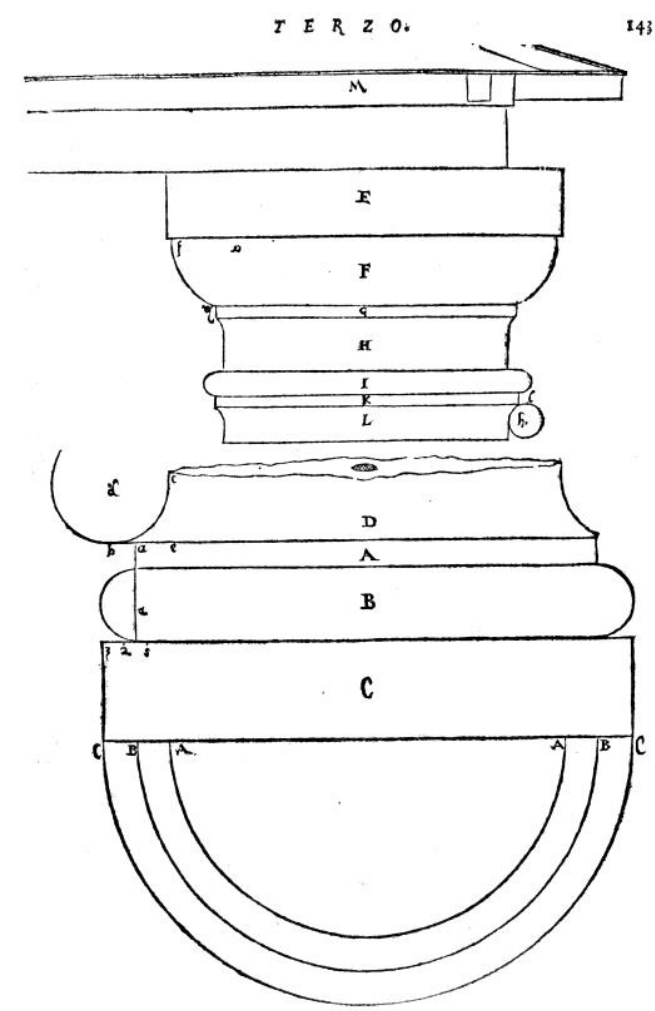

FIG. 2 - Andrea Palladio, the Tuscan order, from Daniele Barbaro's 1567 edition of Vitruvius (Photo: Stiftung Werner Oechslin).

Indeed, in the Quattro Libri, Palladio recognized his debt to Vitruvius in asserting that: "Guided by a natural inclination, I dedicated myself to the study of architecture in my youth, and since I always held the opinion that the ancient Romans, as in many other things, had also greatly surpassed all those who came after them in building well, I elected as my master and guide Vitruvius, who is the only ancient writer on this art [my emphasis]. I set myself the task of investigating the remains of ancient buildings that have survived despite the ravages of time and the cruelty of the Barbarians, and finding them much worthier of study than I had first thought, I began to measure all their parts minutely and with the greatest care". 9 Sebastiano Serlio makes a similar comment in his Regole generali di architettura (1537) in

publici e privati che contendono con gli antichi danno lume a moderni e daranno meraviglia a quelli che verrano [my emphasis]".

${ }^{9}$ Palladio 1570, proemio, 5, "Da natural inclinatione guidato mi diedi ne i mei primi anni allo studio dell'architettura... mi proposi per maestro e guida Vitruvio [my emphasis], il quale è il solo antico scrittore di quest'arte, e mi misi alla investigatione delle reliquie de gli Antichi”. 
characterizing Vitruvius as his "guide and infallible rule". ${ }^{10}$ Similarly, Sir Henry Wotton, traveller, diplomat and scholar, would refer later to Vitruvius as "Our principal Master" in his Elements of Architecture, printed in London in 1624.

In Palladio's relatively short treatise there are as many as seventy-two mentions of the name of Vitruvius and twenty-three reconstructions in books I-III of ancient buildings and architectural details described by him, of which no fewer than thirteen are included in the Second Book dealing with private palaces and villas. ${ }^{11}$ Vitruvius is of fundamental importance for the Renaissance since his De architectura libri decem (Ten Books on Architecture), the only treatise on architecture handed down to us from antiquity, was a text used by Palladio and many other Renaissance architects both as a guide to ancient architecture and as a source of modern design. His treatise can be considered as a founding document establishing the ground rules of the discipline for generations after its first reception in the Trecento and early Quattrocento. ${ }^{12}$

The purpose of this paper is to examine Palladio's relationship to Vitruvius in the Quattro Libri, focusing more particularly on the canonical orders and leaving other aspects of his Vitruvianism, such as his architectural theory, for further publication. It is limited to the Tuscan, Doric, Ionic and Corinthian orders since Vitruvius does not mention the Composite which did not evolve until later, possibly in the first century CE (the Arch of Titus, in the Roman Forum, build in $82 \mathrm{CE}$, is considered one of the first examples of the Composite order). I will investigate the extent of Palladio's adherence or non-adherence to the Vitruvian specifications for the orders and his attitude toward the classical author with regard to this issue. This paper aims to be a useful addition to the studies of Hubertus Günther (1989), ${ }^{13}$ Branko Mitrović (1999 and 2002), ${ }^{14}$ Howard Burns (2008), ${ }^{15}$ and and David Hemsoll (2015) in dealing more specifically with Vitruvius.

This study is deliberately limited in its scope, in taking into consideration only Palladio's canonical orders as they appear in the First Book of the Quattro Libri, rather than extending the analysis to the orders used by Palladio in his own built architecture. His "paper" orders have been (and even today are) scrutinized and often followed by architects wishing to employ a classicising style. Palladio paid great attention to Vitruvius in arriving at usable and elegant forms for the orders, but, as he himself declared, in their proportions and their details he followed his own investigations of Roman antiquities, the fruit of which are partly published in the Fourth Book. An unprejudiced examination of what the ancients did reveals a host of different proportions and details for the orders, even in a context as significant as the Roman Forum. It is easy to see why Renaissance architects were anxious to extract clear and usable principles from this abundance and variety, but the orders they created are a fiction, in which Vitruvius appears to have served as a guide.

\footnotetext{
${ }^{10}$ Serlio 1537, XLVI: "Come guida e regola infalibile". See Peter Hicks and Vaugham Hart's translation of Serlio, On Architecture, New Haven and London, 1996. Hicks and Hart in Palladio's Rome also signal Palladio's relationship with Serlio.

${ }^{11}$ On Palladio and Vitruvius, see especially the recent book by D'Evelyn 2012.

${ }^{12}$ An important study on this phase of reception of Vitruvius's treatise is Ciapponi 1960, 59-99.

${ }^{13}$ See Günther 1990, 182-197.

${ }^{14}$ See Mitrović 1999, 110-140 and Mitrović 2002, 113-127.

${ }^{15}$ See Burns 2008, 37-84,

${ }^{16}$ See Hemsoll 2015, 1-54.
} 


\section{A natural theory of the Orders}

Palladio was not, it must be admitted, primarily interested in abstract speculation and aesthetics, and we can find only a few hints about his theoretical ideas in his treatise. In this respect, the Quattro Libri serves a different purpose from Daniele Barbaro's 1556 and 1567 Italian and Latin editions of Vitruvius, which often contain many learned and abstract theoretical comments. By contrast, Palladio attempted to reduce the length of his written text to a strict minimum, limiting the commentary accompanying the plates of his treatise to a few practical matters of relevance to practising architects. Specific comments about his theory of architecture appear only sporadically in the Quattro Libri, for example in Chapter XX of the First Book, which deals with abuses and more generally with the imitation of nature in architecture. It is in this chapter that Palladio asserts, following Vitruvius and Alberti, that architecture, as the other arts, is an art of imitation of nature: "Architecture imitates nature (as do all the other arts), [and] cannot endure anything that alienates and distances it from what nature herself permits". ${ }^{17} \mathrm{He}$ explicitly connects this statement with the imitation in stone or marble of the carpentry of early wooden structures, which at some stage provided the origin of classical architecture and the orders. He paraphrases the famous Vitruvian account of the origins of building whereby stone gradually supplanted wood and extends this point with an analogy between columns and trees, noting that both taper as they rise upward. ${ }^{18}$ The analogy between columns and trees was probably indebted to two passages in the De architectura, namely the account of the Doric order in Book IV and Vitruvius's recommendations concerning superimposed orders on the forum in Book V. In the second passage Vitruvius made an explicit comparison between a column and a tapering tree which is thicker at the roots: "we really should imitate the nature of things that grow, for example trees with smooth trunks such as fir, cypress and pine, which are all thinker just above the roots, and then, as they develop, reach upwards and grow with a unifirm natural diminution up to the top". ${ }^{19}$

It is in the context of Palladio's statement that architecture imitates nature that he recommends that the ornaments of the classical orders "should be made with a particular effect in mind and should act as examples of what one would see if the building was made of wood ("tutte le parti (...) siano come dimostratici di quello che si vederebbe quando l'opera fosse di legname")". ${ }^{20}$ This statement appears to be based on the following sentence in Vitruvius's De architectura, Book IV, ii, 5: "Ita quod non potest in veritate fieri, id non putaverunt in imaginibus factum posse certam rationem habere" ("One should never make an image of that which could not exist in reality"). Although challenged by Michelangelo and other Mannerist architects, Vitruvius's theory of the imitation in stone or marble of the original details of

\footnotetext{
${ }^{17}$ Palladio 1570, 51: "Dico adunque, che essendo l'Architettura (come ancho sono tutte le altri arti) imitatrice della Natura; niuna cosa patisce, che aliena e lontana sia da quello, che essa Natura comporta: onde noi veggiamo che quegli antichi architetti quali gli Edificij, che di legno si facevano cominciarono a fare di pietre".

${ }^{18}$ Palladio 1570, Book I, 51: “(...) instituirono che le colonne nella cima loro fossero manco grosse, che da piedi, pigliando l'esempio da gli arbori, i quali tutti sono piu sottili nella cima, che nel tronco, e appresso le radici”.

${ }^{19}$ Vitruvius, Book V.i.3: "Non minus quod etiam nascentium oportet imitari naturam, ut in arborus teretibus ... e quibus nulla non crassior est ab radicibus, dein decrescendo proceditur in altudinem naturali contractura peraequata nascens ad cacumen". The translation quoted here is the most recent by Schofield 2009, 120. See also Vitruvius, De architectura, IV.ii.1-3. See also Boucher 2000, 296-311 (especially 305).

${ }^{20}$ Palladio 1570, Book I, 51.
} 
wooden structures remained valid until the mid-eighteenth century when the Venetian Observant Franciscan friar and architectural theorist Carlo Lodoli (1690-1761) and his nineteenth-century followers subsequently condemned classical architecture as highly deceptive and not true to the nature of materials, in another words dishonest and fallacious. ${ }^{21}$ Vitruvius had indeed suggested that the different members of classical architecture could be traced from the carpentry of primitive wooden dwellings. According to Vitruvius, the columns, the pediments and the other main parts of the classical orders, such as frieze and entablature, were at some time changed from wood to stone or marble, and the particular forms, especially those of the Doric and Ionic orders, resulted from this (Chapter 2 of Book IV, 1-5).

Although both Palladio and Barbaro recommended that the details of the classical orders should be rational and faithful to their wooden origins, they disagreed with Vitruvius on the use of mutules (modioni) and dentils in the raking cornices of pediments. According to Vitruvius, the principal rafters (asseres) of the wooden roof were the forerunners respectively of the mutules and the dentils of the Doric and Ionic orders. These architectural elements were to be avoided in the sloping cornices of a pediment because they represent parts in a wooden roof that could not appear in that position. Barbaro considers, however, that such an irrational use of the mutules and dentils was sanctioned by ancient examples and was, therefore, permissible. ${ }^{22}$ Indeed Palladio's relevant illustration of the Ionic order in Barbaro's Vitruvius shows dentils in the raking cornices of the pediment, in clear opposition to Vitruvius's recommendations.

\section{The antiquities vs Vitruvius}

In contrast to Daniele Barbaro, who considers Vitruvius to be an almost unquestionable and unerring architectural authority, Palladio, in Chapter XII of the First Book, entitled "On the five orders used by the ancients", mentions explicitly that he did not follow Vitruvius in his codification, stating that his canonical orders are given "not so much in line with what Vitruvius teaches but according to what I have observed in ancient buildings". ${ }^{23}$ Similarly, Giacomo Barozzi da Vignola (1507-1573) in his Regola delli cinque ordini (1562), explains in his address to the reader that he had decided to formulate a canon based exclusively on his own first-hand study of "the antiquities of Rome". He explains that in establishing the details of this canon, he was "taking entirely from the ancients, and not mixing anything of my own", which he adds was "not as Zeuxis did with the virgins of Croton". ${ }^{24}$ Vignola refers here to the Greek artist Zeuxis (464-398 BCE) who, when painting a portrait of Helen, summoned the local girls from Croton to parade before him and then chose five on the basis of seeing their brothers exercising naked, in order to incorporate the best features of each of them (Cicero, De Inventione, ii, 1-3). ${ }^{25}$ Despite Vignola's claim not to have mixed various sources in each of his canonical orders, it seems likely that this did not apply to Palladio's

\footnotetext{
${ }^{21}$ On Carlo Lodoli, see especially Cellauro 2006, 25-59.

${ }^{22}$ Barbaro 1567, 171.

${ }^{23}$ Palladio 1570, 15: "Non tanto secondo che m'insegna Vitruvio, quando secondo c'ho avvertito negli edifici antichi".

${ }^{24}$ Barozzi da Vignola 1562, address to the reader.

${ }^{25}$ For Cicero's anecdote of Zeuxis and the virgins of Croton, see arkan 2000, 99-109.
} 
FIG. 3 - Andrea Palladio, The Composite entablature, from I Quattro Libri dell'Architettura, Venice, 1570 (Photo: Stiftung Werner Oechslin).

compositional method. Indeed Palladio's working procedure seems to have consisted of choosing the best details and proportions from the orders of ancient architecture (as Zeuxis did in painting the virgins of Croton), not so much from Vitruvius as from the extant buildings themselves, giving therefore more authority to surviving ancient examples than to the descriptions of Vitruvius which were often not confirmed by archaeological evidence. For example, his composite order, as illustrated on plate 50 of the First Book of the Quattro Libri (FIG. 3), shows a combination of details taken from various ancient buildings, namely the capital and the two-fasciae architrave of the Arch of Severus, the convex frieze of the Composite order of Santa Costanza in Rome, and the modillions of the temple of Serapis on the Quirinal Hill, whose entablature was known during the Renaissance as the "Frontespizio di Nerone". Palladio also made the effort to combine and adjust the proportions surveyed on different Roman remains, his procedure being that of searching for the best possible combination of the proportions of elements. The proportions of the largest elements (architraves, friezes and cornices) are consequently the results of such an empirical procedure, probably arrived at as sums of the proportions of individual elements. 


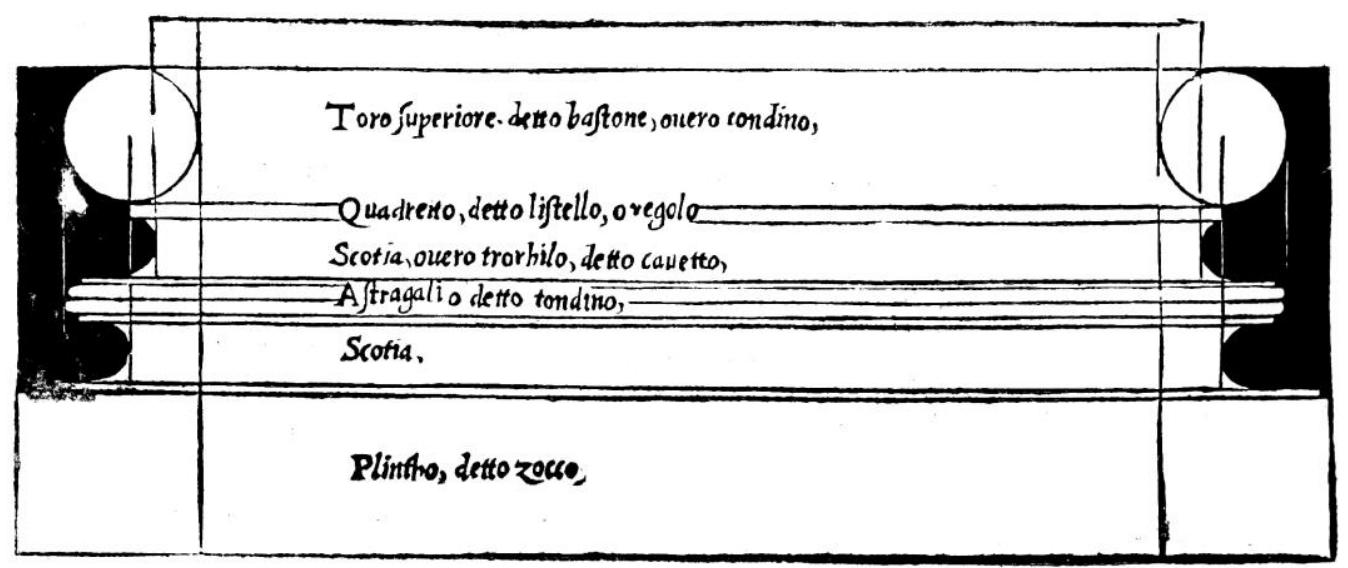

FIG. 4 - Sebastiano Serlio, The Vitruvian Ionic base, from Regole generali di architettura, Venice 1537 (Photo: Stiftung Werner Oechslin).

Palladio's procedure of selecting the best details and proportions from extant ruins denotes a critical attitude towards the classical author, typical of the Renaissance. Other Renaissance architectural theorists were also critical of Vitruvius. For example, Baldassare Peruzzi (14811536), according to Giorgio Vasari (1511-1574), planned an illustrated commentary on Vitruvius, but adopted a critical and independent attitude towards the ancient treatise. Of Peruzzi's attitude Benvenuto Cellini (1500-1570) writes in his Discorso dell'architettura: "To have a clearer idea of the best manner of architecture, he [Peruzzi] subjected himself to draw all the styles "the Vitruvian modus" of ancient buildings of Rome ... and many times he said that he knew that Vitruvius did not choose the most beautiful, because he was neither a painter nor a sculptor". ${ }^{26}$ It is likely that it is in connection with the orders that Peruzzi expressed this critical comment. The degree of adherence to the Vitruvian orthodoxy of many sixteenth-century architects can also be judged from the rarity of their use of the Vitruvian Ionic base (consisting of an upper torus, a scotia, a double astragal, and another scotia immediately beneath a plinth), which in fact was never found in surviving Roman buildings. It was reconstructed first by Fra Giovanni Giocondo (1433-1515) in 1511 and by Serlio in his Regole generali di architettura of 1537 (Book IV) (FIG. 4), although it had been used in only

\footnotetext{
${ }^{26}$ Cellini 1971, 817-818: "Per meglio chiarirsi qual fussi la migliore maniera dell'architettura, si sottomesse [Peruzzi] a ritirare tutte le maniere che egli vedeva delle cose antiche di Roma ... E molte volte disse che conosceva che Vitruvio non aveva scelto di queste belle maniere la più bella, si come quello non era né pittore né scultore". For the issues of rule and liberty that the Cellini quotation presupposes, see Summers 1972, 146-57 and Summers 1981.
} 
FIG. 5 - Andrea Palladio, The Ionic capital and Ionic Vitruvian base, from I Quattro Libri dell'Architettura, Venice, 1570 (Photo: Stiftung Werner Oechslin).

a few Renaissance buildings. Jacopo Sansovino (1486-1570) in the lesser Ionic order of his Libreria in 1537, Gian Giorgio Trissino for his villa at Cricoli in the late 1530 s, Vignola in the cortile of the $\mathrm{Pa}$ lazzo Farnese at Caprarola in 1557, Galeazzo Alessi (1512-72) in the façade of Palazzo Marino in Milan in 1557, and Giovanni Battista Bertani (1516-76) - author of a partial commentary on Vitruvius in the Vitruvian portal of his house in Mantua in the 1550s, all followed Vitruvius. ${ }^{27}$ But a majority of practicing architects, including Bramante (1443-1514), Raphael (1483-1520), Pirro Ligorio (151383) and Antonio da Sangallo the Younger (1484-1546), resisted Vitruvian conformism by using in their Ionic orders the Attic base or a type of Ionic base employed in Roman times, which resembles the Vitruvian Ionic base. In the Quattro libri, Palladio describes the Vitruvian Ionic base and includes an illustration of it on Plate 34 (FIG. 5). He states, however, that "because we can see that Attic bases, which please me better, were used with this order in many ancient buildings, I have drawn above the pedestal with that little torus [bastoncino] under the cimbia, though I have not neglected to make a drawing of the type Vitruvius taught us about". ${ }^{28}$ A study of the Vitruvian Ionic base dating from the early 1540s is preserved at the Royal Institute of British Architects (RIBA XI.9 verso). Palladio's reconstructions using the Ionic order in Barbaro's Vitruvius (the dipteral, the peripteral, and the eustyle pseudodipteral temples and the Ionic doorway) all use the Vitruvian Ionic base. In his own

\footnotetext{
${ }^{27}$ See Burns 1988, 207-26.

${ }^{28}$ Palladio 1570, 31: "Ma perche in molti edificij Antichi si veggono a quest'ordine base Attiche, e a me più piacciono, sopra il piedestilo ho disegnato l'Attica con quel bastoncino sotto la Cimbia; non restando però di fare il disegno di quella, che ci insegna Vitruvio".
} 
buildings, Palladio, however, used only once the Vitruvian Ionic base, namely in the windows of the Palazzo Porto in Vicenza (c. 1549). ${ }^{29}$

\section{Palladio and the Renaissance codification of the Orders}

The five orders as presented by Palladio in the Quattro Libri represented a recent codification. Only in the sixteenth century did an approach to the proportions and what might be called the identity of the orders come into common use. ${ }^{30}$ Raphael defined the five orders as used by later architects in his letter to Leo X written sometime between 1513 and 1519. Serlio first published in his Regole generali di architettura of 1537, the total set of orders with all its parts, and Vignola's Regola delli cinque ordini presented the orders more clearly than Serlio had done, giving illustrations of freestanding and engaged columns, a procedure followed by Palladio. For the proportional system adopted by Serlio, Vignola, and Palladio, Vitruvius offered few insights. He advocated a proportion of 1:7 (diameter to height) for the Tuscan and Doric orders, 1:9 for the Ionic and 1:9 2/3 for the Corinthian, but did not consider the Composite order. Characteristically, Palladio and his immediate predecessors were guided by their own aesthetic bias when they came to this topic. Serlio gave proportions of 6, 7, 8, 9 and 10 for the heights of the Tuscan, Doric, Ionic, Corinthian, and Composite orders, while Vignola recommended $7,8,9,10$ and 10 for the same sequence. Palladio adopted a different course. He followed Vitruvius's rule for the Tuscan and Ionic orders (i.e 1:7 and 1:9 respectively) but he adjusted the Doric order to 1:7.5 and specified the Corinthian and Composite orders as 1:9.5 and 1:10 respectively.

Although Palladio based his orders on in his personal aesthetic choice of the best examples in extant ancient buildings rather than on the descriptions of Vitruvius, his codification appears to be more influenced by the classical author than those of his predecessors such as Serlio and Vignola. This is also evident in Palladio's plate in the Quattro Libri of the freestanding Tuscan order (FIG. 1), which is almost identical to Vitruvius's specifications and to the plate Palladio designed for Barbaro's edition of Vitruvius (FIG. 2). Vitruvius did not discuss the Tuscan order in his chapters on the canonical orders of antiquity (Doric, Ionic and Corinthian), but peripherally, in his description of the Etruscan temple in Book IV, vii. The Vitruvian description of the Tuscanicae dispositiones is much less specific than the canonical orders. It gives only a few indications of the modular proportions of the base, and the overall height of the column and of the capital. The only specific clue to the appearance of the column is the statement that the plinth is circular (on the other orders it is square) and that the base mouldings are limited to a single torus and a collar. The nature of the capital and of the entablature is not divulged.

Palladio mentions in his treatise that his version of the Tuscan order is after Vitruvius (IV.vii.2-4), which stipulates that the column shafts should have a diameter one-seventh of their height and an entasis of one-quarter of their diameter at the bottom. The bases are to be made a diameter high and with a circular plinth ("Habeant spirae earum plinthum ad circinum") which is half the height of the base, with a torus and apophysis as deep as the

\footnotetext{
${ }^{29}$ See Beltramini and Burns 2008, 75.

${ }^{30}$ See particularly Thoenes 2002a, 199-213; Thoenes 2002b idem, 352-361; Guenther 1989, 154-168. For Palladio and the orders, see Guenther 1990, 182-197; Mitrović 1999, 110-140; and Mitrović 2002, 113-127.
} 
plinth. Above the columns, wooden beams are to be bolted together (trabes compactiles) and should have a thickness equal to the hypotrachelium at the top of the column. Finally, above the beams there are joist-ends (mutules) the projection of which is to be one-quarter of the height of the column (Palladio, however, in his accompanying plate reduced this projection to $3 \frac{3}{4}$ modules of the column height). "The Tuscan order," Palladio writes, "according to Vitruvius, and as seen in practice, is the barest and simplest of all the architectural orders since it retains its original antique character, and lacks all those ornaments that render the others worthy of attention and beautiful. It originated in Tuscany, the noblest part of Italy, whence it acquired its name". ${ }^{31}$ The expressive and symbolic role of the order is much more limited than Serlio suggested in his Regole: "The Tuscan, being rough", Palladio says, "is rarely used above ground except in one-storey buildings like villa barns or in huge structures such as amphitheatres and the like which, having many orders, may take this one in place of the Doric, under the Ionic". 32

\section{The proportions of the Doric, Ionic and Corinthian entablatures}

In Chapter Three of Book IV, Vitruvius gives the proportions and symmetry of the Doric genus, including the proportion of the Doric entablature in relation to the height of the column. Palladio summarized Vitruvius's specifications in stating that "The architrave, frieze, and cornice end up a quarter as tall as the column. And these are the dimensions of the entablature according to Vitruvius, from which I departed in some respects, altering some of the details and making it a little larger". ${ }^{33}$ Indeed Palladio replaced the cymatium mentioned by Vitruvius above the triglyphs by a cavetto and an ovolo separated by a filet. The height of the cornice of Palladio's Doric is 33 minutes, the height of the frieze 50, and of the architrave 80. Consequently, the height of the entablature is 113 minutes. Palladio has thus slightly enlarged the Doric entablature by 2 minutes, but the proportions still remain very Vitruvian at almost exactly one-quarter of the column height.

Palladio did not pay attention to Vitruvius's guidelines for the proportions of the Ionic entablature, namely that the heights of the architrave are to be determined in accordance with the variation in height of the columns. In Book III.v.8-12, Vitruvius formulated the guidelines for constructing the Ionic entablature, stating first that the architraves - because of optical considerations - are to be in proportion with the height of the columns. For example, with columns from twelve to fifteen feet, the height of the architrave should be half the width of the column at the base; with columns from fifteen to twenty feet, their height should be divided in thirteen parts, one part of which should be the height of the architrave; with

\footnotetext{
${ }^{31}$ Palladio 1570, Book I, 16: "L'ordine Toscano, per quanto ne dice Vitruvio, e si vede in effetto, è il piu schietto, e semplice di tutti gli ordini dell'Architettura: percioche ritiene in se di quella primiera antichità, e manca di tutti quegli ornamenti, che rendono gli altri riguardevoli, e belli. Questo hebbe origine in Toscana nobilissima parte di Italia, onde anco si serba il nome".

${ }^{32}$ Palladio 1570, Book I, 15: "Il Toscano, come rozo, si usa rare volte sopra terra, fuor che nelle fabriche di un'ordine solo, come coperti di Villa: overo nelle machine grandissime, come Anfitheatri, e simili: lequali havendo piu ordini, questo si ponerà in luogo del Dorico sotto il Ionico".

${ }^{33}$ Palladio 1570, Book I, 26: "Onde l'Architrave, il Fregio, e la Cornice vengono ad esser alti la quarta parte dell'altezza della colonna. E queste sono le misure della Cornice secondo Vitruvio: dalla quale mi sono alquanto partito alterandola de' membri, e facendola un poco maggiore".
} 
columns from twenty to twenty-five feet, their height should be divided into twelve and a half parts, one part of which should be the height of the architrave; and with columns from twenty-five feet to thirty feet, their height should be divided into twelve parts of which one part should be the height of the architrave. By contrast, Palladio does not mention the variation of the height of the entablature in accordance with the height of the column and proposes a fixed ratio of 1/5: "The architrave, frieze, and cornice are (as I said) a fifth of the column height". ${ }^{34} \mathrm{He}$ also reconstructed the Ionic entablature with a pulvinated frieze, although Vitruvius did not explicitly describe the frieze as such in the relevant section. Pulvinated friezes do not appear in the Vitruvian Ionic, because they are an Etruscan motif that shows up in Medieval Tuscany. ${ }^{35}$ Fra Giocondo had included in his edition of Vitruvius an illustration of the Ionic entablature with a flat frieze. The first use of the Ionic pulvinated frieze in Renaissance architecture appears in Raphael's Loggia of Villa Madama, designed at the end of the first decade of the sixteenth century. His reconstruction owes much to Fabio Calvo's translation of Vitruvius which was made specifically for the use of the artist. In a marginal note in the section on the Ionic entablature in his translation preserved in manuscript in Munich, he writes: "nota che parla del fregio pulvinato". ${ }^{36}$ This statement may be compared with the phrase "in li fregi pulvinati e nelli ionici architravi", which appears in Book I of Calvo's translation. ${ }^{37}$ A pulvinated frieze in connection with the Ionic order also appears in Guillaume Philandrier's Latin commentary on Vitruvius, first published in 1544 in Rome: this might have been Palladio's source. Serlio could have been an alternative source for Palladio's pulvinated frieze, who notes this in Book IV (1537), folio XXXIXV.

Corinthian entablatures, unlike the Doric and the Ionic, had not yet been standardized by Palladio's time. ${ }^{38}$ Vitruvius says that the Corinthian column does not have an entablature proper to it, but can be placed under either a Doric or an Ionic one. He is mistaken here, for the Corinthian order did, in fact, end up having its own distinctive entablature, but he does not anticipate this. So it was, he concludes, that "when the (Corinthian) capital had been put between them in works, the two orders (Doric and Ionic) engendered a third one". ${ }^{39}$ In Palladio's version, the column is allowed a height of only $9 \frac{1}{2}$ diameters, instead of $92 / 3$. Both dentils and modillions are prescribed for the entablature, though curiously, in both his general plates of the order, the dentils are omitted, leaving a plain band between the ovolo and cyma reversa of the lower part of the cornice - perhaps an error on the part of the engraver. Serlio, following Vitruvius, has given to the order an Ionic entablature with dentils. Palladio gives to the Corinthian order an entablature a fifth of the height of the column consisting of a cornice with modillions and dentils, a pulvinated frieze, and an architrave with the fasciae divided by astragals. "The architrave, frieze, and cornice", he writes, "are (as I said) a fifth of the column height", giving therefore to the Corinthian entablature the same proportion as his Ionic order, probably on account of a Vitruvian influence. Branko Mitrović

\footnotetext{
${ }^{34}$ Palladio 1570, Book I, 35: "L'architrave, il Fregio, e la Cornice sono (come ho detto) per la quinta parte dell'altezza della colonna".

${ }^{35}$ See Gabrielle Morolli 1985; Edlund-Berry 2000.

${ }^{36}$ See Fontana and Morachiello 1975, 165. See also Burns 1984, 390.

${ }^{37}$ See Fontana and Morachiello 1975, 80.

${ }^{38}$ See Mitrović 2002, 115.

${ }^{39}$ Vitruvius, IV.i.3: "Ita e generibus duobus capitulo interposito tertium genus in operibus est procreatum”.
} 
has pointed out that Vignola's Regola, first published in 1562, is the main source of Palladio's canonical Corinthian entablature. ${ }^{40}$ When it comes to the forms and placement of the elements of the entablature, the canonical Corinthian entablature presented in Book I of the Quattro Libri is almost identical (except in a few very small details) with the one Vignola had proposed seven years before the publication of Palladio's treatise. But while Palladio's version of the Corinthian entablature has almost the same morphology, it differs significantly from Vignola's when it comes to the proportions of the details, particularly of the total height of the entablature. In Palladio's Corinthian it is 1.881 diameters of the lower column (E/D), while Vignola's is 2.542. Among almost one hundred illustrations presented in the last book of I Quattro Libri, there are nineteen that show details of Corinthian entablatures, carefully drawn and measured. Their proportions, studied by Mitrović, show that the height of Palladio's entablature (1/5 of the height of the column) is close to those of the Circular Temple near the Tiber, the Temple of Minerva in Assisi, and the Basilica of Maxentius (E/D respectively of $1.809,1.902$, and 1.751$).^{41}$

\section{$V$. Three Vitruvian issues: the width of the Doric capital, the height of the Corinthian capital, and the baseless Doric order}

The main motivation for the critical attitude to Vitruvius during the Renaissance was the discrepancy between many of Vitruvius's recommendations and the measurements taken from extant ruins. Despite Barbaro's enthusiastic Vitruvianism, his reading of the De architectura libri decem brought out a number of important issues where he disagreed with his ancient model, including the orders described by Vitruvius. He offered modifications of Vitruvian recommendations, such as his preference for a greater projection of the abacus of the Doric capital than that suggested by Vitruvius, and his observation that a capital that was only two and one-sixth modules wide appeared to him very small: "The width [of the capital] is equal to the thickness of the column plus one-sixth, according to Vitruvius. But in the antique we find one-fifth for each part, and this looks better". ${ }^{42}$ He therefore suggested a Doric capital two and two-fifths modules as in such extant ancient examples as the Theatre of Marcellus and the Doric temple at St. Nicola in Carcere. Alternative solutions appeared in Jean Martin's French translation of Vitruvius of 1547 and in Serlio's book IV of 1537 (FIGS. 6-7). In Palladio's illustration of the Doric capital for Barbaro's Vitruvius published in 1556, the projection of the abacus appears to follow Vitruvius's specifications, although this illustration was suppressed in 1567 and replaced by an illustration by Palladio of the Doric order that shows a projection of the abacus in accordance with Barbaro's own specifications (FIGS. 8-9).

In the same way, a Corinthian capital, the height of which was to be equal to the lower diameter of the column, as recommended by Vitruvius, seemed to Barbaro too small when compared to similar ancient specimens: "The Corinthian capital", writes Barbaro, "is as high

\footnotetext{
${ }^{40}$ See Mitrović 2002, 116.

${ }^{41}$ These proportions are given by Mitrović 2002, 120.

${ }^{42}$ Barbaro 1567, 145: "La larghezza [del capitello] è tutta la grossezza della colonna, e di più un sesto. Ma nell'antico si trova, e riesce meglio un quinto per parte".
} 

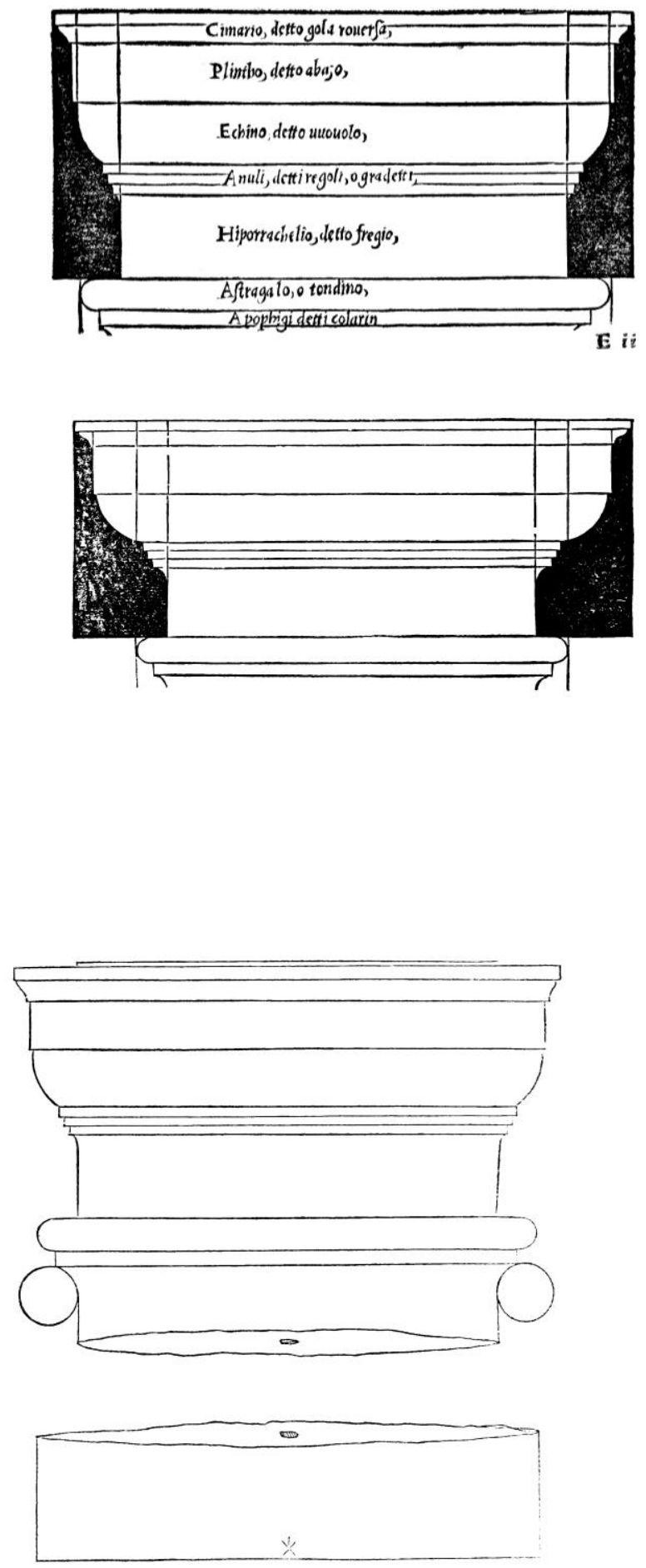

FIG. 6 - Sebastiano Serlio, The Doric capital after Vitruvius, from Regole generali di architettura, Venice 1537 (Photo: Stiftung Werner Oechslin).

FIG. 7 - Sebastiano Serlio, The Doric capital with a projection of the abacus of two-fifths, from Regole generali di architettura, Venice 1537 (Photo: Stiftung Werner Oechslin).

FIG. 8 - Andrea Palladio, The Doric capital after Vitruvius, from Daniele Barbaro's 1556 edition of Vitruvius (Photo: Stiftung Werner Oechslin).

FIg. 9 - Andrea Palladio, The Doric capital with a projection of the abacus of twofifths, from Daniele Barbaro's 1567 edition of Vitruvius (Photo: Stiftung Werner Oechslin).

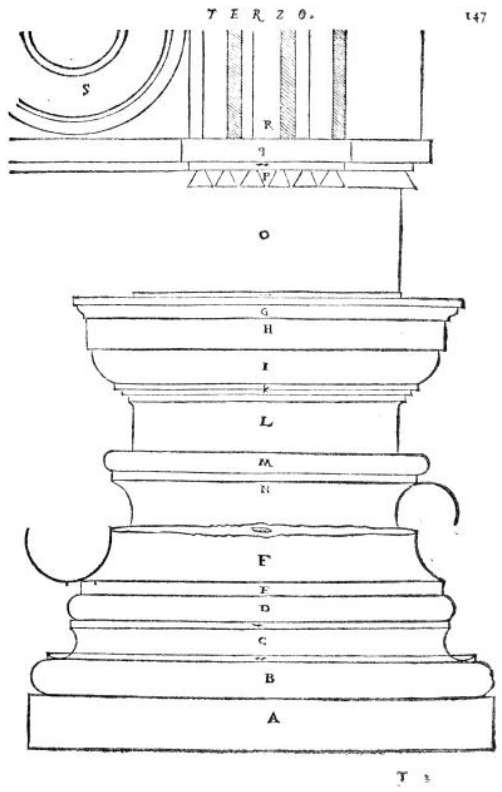


as the diameter of the column, and according to Vitruvius, in this height the abacus is included, but in many [ancient] works, the abacus is not included, and it looks better". ${ }^{43}$ According to Barbaro, the height of the Corinthian capital should therefore be one and oneseventh diameters (1.143) instead of the one diameter recommended by Vitruvius, giving greater slenderness to the capital. As stated by Barbaro, most of the best preserved Roman Corinthian capitals known to the Renaissance did not follow Vitruvius's rules. Mark Wilson Jones gives the following ratios between the height of the Corinthian capital and the lower diameter of the column: Round Temple by the Tiber (type 1): 1.27; Round Temple by the Tiber (type 2): 1.32; Temple of Mars Ultor: 1.13; Temple of Castor: 1.09; Temple of Vespasian: 1.20; Pantheon interior: 1.13; Pantheon Portico: 1.10; Temple of Hadrian: 1.25; Temple of Antoninus and Faustina: 1.12. ${ }^{44}$ The only Roman example known to the Renaissance which conforms approximately to Vitruvius's recommendations is the Temple of the Sibyl at Tivoli where the height of the capital in relation to the lower diameter of the column is 0.97. Palladio's illustration for Barbaro's 1556 edition of Vitruvius, however, does not follow the recommendations suggested by Barbaro in his accompanying commentary, but those of Vitruvius. This suggests, as in the case of the Doric capital, that Barbaro intended his illustrations to be a faithful reconstruction of Vitruvian architecture.

As stated in the written commentary accompanying the relevant plate of the Quattro Libri, Palladio follows Barbaro in giving the abacus of the Doric capital a projection of one-fifth for each part ("the whole projects by one-fifth of the diameter of the column"), ${ }^{45}$ but gives the Corinthian capital one and one-sixth diameters in height (1.166), instead of the one and oneseventh diameter stipulated by Barbaro. ${ }^{46}$ Palladio's Corinthian capital conforms approximately to those of the Pantheon interior and the temple of Mars Ultor. Thus, although both Barbaro and Palladio considered Vitruvius an authority, they did not hesitate to adopt a critical attitude towards him on the basis of important differences observed in extant archaeological examples.

The Doric order in Palladio's Quattro Libri and for the 1556 edition of Vitruvius is illustrated baseless in accordance with the Doric orders of the Theatre of Marcellus and St. Nicola in Carcere. In two respects the proportions established by Vitruvius are not followed by Renaissance writers or Palladio. First Vitruvius restricts the column height to 7 diameters, producing a rather bulky form, and second, presumably following Greek practice, he offers no dimensions for a moulded base, so that the Vitruvian Doric column rises abruptly from the stylobate. Serlio discusses the absence of bases from Vitruvian Doric at some length, and concludes that the Attic base to which Vitruvius refers elsewhere is the proper base for the Doric. Barbaro writes in this respect: "The Doric order does not have a specific base, but occasionally an Attic base is used with it". ${ }^{47}$ Similarly, Palladio comments in the Quattro Libri: "This order does not have its own base so that in many buildings columns can be seen without bases, as in the Theatre of Marcellus, in the Tempio della Pietà near that theatre

\footnotetext{
${ }^{43}$ Barbaro 1567, 155: "Il capitello Corinthio è alto quanto il diametro della colonna, e secondo Vitruvio in questa altezza s'include l'Abaco; ma in molte opere l'abaco è di più, e ha molto del buono".

${ }^{44}$ See Jones 1991, 89-150.

${ }^{45}$ Palladio 1570, 26.

${ }^{46}$ Palladio 1570, 42.

${ }^{47}$ Barbaro 1567, 144: “(...) il Dorico non ha basa propria, ma alcuna fiata se le dà la basa attica”.
} 
[Palladio RIBA VIII 5, XI 3v; Serlio 1566 III, folios 58v-60r], in the Theatre of Vicenza, and in various other places. But sometimes the Attic base is used with it, which greatly increases its beauty". ${ }^{48}$ In his own buildings, Palladio used consistently the Attic base rather than the baseless Doric, except on three occasions, that is in the outbuildings (barchesse) of the Villa Badoer at Fratta Polesine, in the sala of the Villa Pisani at Montagnana, and in the atrium of the Palazzo Porto at Vicenza.

\section{The module and intercolumniations}

Palladio adopted the Vitruvian module in the composition of his orders, that is to say the diameter of the column shaft, except for the Doric in which, following Vitruvius, he divided the shaft of the column into two modules. He writes in Chapter XIII of the Quattro Libri: “ “ (...) I am aware that units of measurement differ just as cities and regions do: but, imitating Vitruvius, who divides up the Doric order with a unit of measurement derived from its thickness [grossezza], I too will make use of such a unit for all the orders; the module will be the diameter of the column at the bottom divided into sixty minutes, except for the Doric, for which the module will be half the diameter of the column divided into thirty minutes, because that is more appropriate for the elements [compartimento] of this order. Consequently, by making the module larger or smaller depending on the type of building, anyone will be able to use the proportions and profiles [sacoma] appropriate to each order drawn in this book". ${ }^{49}$ The origin of the module is to be sought in the De architectura of Vitruvius which uses the various terms modulus, embater and rata pars, a common measure that constitutes the base or reference unit of all measurements in the same building. Book II.vii.3 of Vitruvius returns to the definition of the modulus given in I.ii.2: "quantitas autem est modulorum ex ipsius operis "membris" sumptio". The modulus is the "smallest" measure common to all dimensions of a building; it is so to speak the lowest common denominator which ensures the commodulatio of the whole. The module generates the exacta ratio or modular relationship between the different parts. The comparison of the module and the lower diameter of the column presented as an inviolable rule in Book III.vii.4 in reality only applies to the Tuscan, Ionic and Corinthian; the module of the Doric order is equivalent to a half-diameter (IV.iii.4): "Crassitudo columnarum erit duorum modulorum altitudo cum capitolo XIIII".

However Vitruvius did not define a systematic internal division of the module, as would be done for the first time in the middle of the sixteenth century by Vignola, and later by Palladio. The latter invented a system, which would be adopted by Vincenzo Scamozzi, and later by Fréart de Chambray, Francois Blondel and Antoine Desgodets. Palladio in fact

\footnotetext{
${ }^{48}$ Palladio 1570, Book I, 22: "Non ha quest'ordine Basa propria: onde in molti edificij si veggono le colonne senza base, come in Roma nel Theatro di Marcello, nel Tempio della Pietà vicino a detto Theatro, nel Theatro di Vicenza, e in diversi altri luoghi. Ma alcuna volta vi si pone la Basa Attica: laquale accresce molto di bellezza".

${ }^{49}$ Palladio 1570, Book I, 16: "Sapendo che le misure sono diverse, come sono diverse le citta. e le regioni: Ma imitando Vitruvio, il quale partisce, e divide l'ordine Dorico con una misura cavata dalla grossezza della colonna, la quale è comune à tutti, e da lui chiamata Modulo; mi serviro ancor io di tal misura in tutti gli ordini, e sarà il Modulo il diametro della colonna da basso diviso in minuti sessanta, fuor che nel Dorico: nel quale il Modulo sarà per il mezo diametro della colonna, e diviso in trenta minuti; perche cosi riesce piu commodo ne' compartimenti di detto ordine. Onde potrà ciascuno facendo il Modulo maggiore, e minore secondo la qualità della fabrica servirsi delle proportioni, e delle sacome disegnate a ciascun' ordine convenienti”.
} 
divided the diameter of the Doric order into two modules of thirty minutes and the diameters of the Tuscan, Ionic, Corinthian and Composite orders into a single module of sixty minutes. The division into sixty minutes of the diameter or of two half-diameters into thirty minutes, seems clearly to be based on an interpretation of the theory of perfect numbers formulated by Vitruvius in Book III, I, 5-6: "It is worthy of remark, that the measures necessarily used in all buildings and other works are derived from the members of the human body, as the digit, the palm, the foot, the cubit, and that these form a perfect number, called by the Greeks $\tau \dot{\lambda} \lambda \varepsilon 10 s$. The ancients considered ten a perfect number, because the fingers are ten in number, and the palm is derived from them, and from the palm is derived the foot. Plato, therefore, called ten a perfect number, Nature having formed the hands with ten fingers, and also because it is composed of units called $\mu$ ová $\delta \varepsilon \varsigma$ in Greek, which also advancing beyond ten, as to eleven, twelve, \&c. cannot be perfect until another ten are included, units being the parts whereof such numbers are composed. The mathematicians, on the other hand, contend for the perfection of the number six, because, according to their reasoning, its divisors equal its number: for a sixth part is one, a third two, a half three, two-thirds four, which they call $\delta$ ínorpos; the fifth in order, which they call $\pi \varepsilon v \tau$ ó $\mu$ orpos, five, and then the perfect number six. When it advances beyond that, a sixth being added, which is called है $\varphi \varepsilon \kappa \tau o \zeta$, we have the

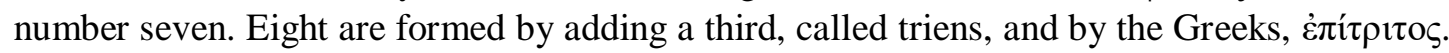
Nine are formed by the addition of a half, and thence called sesquilateral; by the Greeks $\dot{\eta} \mu$ tó $\lambda$ tos; if we add the two aliquot parts of it, which form ten, it is called bes alterus, or in

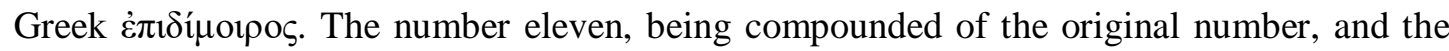

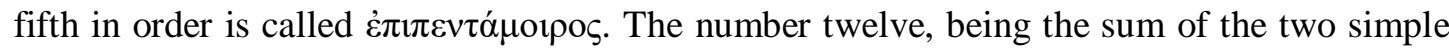
numbers, is called $\delta \imath \lambda \alpha \sigma i ́ \omega v "$.

The numbers 6 and 10, considered in ancient Greece and by Vitruvius numeri perfecti, were used by Palladio to determine the module because the number 60 is a multiple of them. He was followed in this by Scamozzi, who extended the principle of the module of sixty minutes to all orders and, concerning this division, noted that "The module can be divided in various ways, but the best is into 60 equal parts, this number being a rational number and the product of 6 and 10. Perfect numbers have a compound, which is perfect. It contains within itself 10 complete divisions; such as the small numbers $2,3,4,5$ and 6 , which is the same as saying $1 / 2,1 / 3,1 / 15,1 / 12,1 / 10$ and in addition the larger numbers 10, 12, 15, 20 and 30, which indicate $1 / 6,1 / 5,1 / 4,1 / 3$ and $1 / 2 " .50$ It is likely that perfect numbers played as important a role as harmonic proportions in Palladio's design process, but this has been little investigated so far. Robert Tavernor has pointed out that Palladio's Basilica in Vicenza is indeed based on perfect numbers. ${ }^{51}$

Palladio also adopted Vitruvius's specifications about intercolumniation. Vitruvius expressed the variety of distance between columns in temple porticoes in terms of column

\footnotetext{
${ }^{50}$ Scamozzi 1615, 4: "Il modulo si puo' dividere in molti modi; mà invero riesce meglio in LX parti uguali; essendo numero rationale, e prodotto dal 6 e dal 10. Ambi perfetti, e percio' egli perfettissimo; e che comporta in se X divisioni intere; come il 2.3.4.5 e il 6 . de numeri minori , che è quanto a dire $1 / 3,1 / 2,1 / 15,1 / 12$, e $1 / 10$. e poi il 10, 12, 15, 20 e il 30 ".

${ }^{51}$ See Tavernor 1991, 36: "A rhythm of 6-10-6 piedi (solid-void-solid) between the centres of the half-columns of the trabeated frame is established. This combination of the numbers 6 and 10 pervades the "ideal" design that Palladio presents: the ambulatory around the building is given the depth of 16 piedi".
} 
diameters, such as the araeostyle, the diastyle, the eustyle, the systyle, the picnostyle, a Vitruvian Greco-Roman vocabulary, which Palladio uses in book 4 of the Quattro Libri. He follows Vitruvius in stating that the eustyle of two and a quarter diameters is "the most beautiful and suitable kind of intercolumniation". ${ }^{2}$ Vitruvius saw intercolumniation as a separate issue from the height of columns, but his use of column diameters in this context led to an assumed link on the part of his Renaissance readers. Palladio, however, was aware of the distinction between the two issues and prefaced his own account of the proper distance between types of orders as only examples of what Vitruvius had in mind. Thus the Tuscan order which carried a wooden entablature and was characterized by Palladio as "bassa, larga et umile" was matched with the areostyle intercolumniation of 4 diameters; the Doric was aligned with the diastyle of 2.75 diameters, as against 3 diameters in Vitruvius, in order to avoid cracking the architrave; the Ionic order was matched with the eustyle of 2.25 diameters; the Corinthian went with the systyle of 2 diameters and the Composite keyed to the picnostyle of 1.5 diameters.

\section{Optical corrections}

Palladio seems, however, to have diverged from Vignola and many other Renaissance architects on one essential point of theory. The Bolognese architect insisted in the preface of his Regola that his specifications for the orders were not to be regarded as unalterable rules. They were, on the contrary, guidelines that intelligent architects guided by their acumen could modify according to visual conditions - as Vitruvius recommended in books V.vii.7, VI.ii. 2-4, and VI.iii.11, by "adding to or subtracting from the proportional system" ["cum de symmetria sit detractum aut adiectum"], which was translated by Vignola as "secondo il parere di tutti e massime di Vitruvio molte volte conviene crescere o scemare [my emphasis] dalle proportioni de membri delli ornamenti per supplire con l'arte dove la vista per qualche

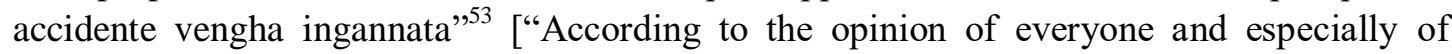
Vitruvius it is often necessary to enlarge or to reduce the proportions of the parts of the ornaments in order to compensate artificially for the imperfections of our vision"]. This important point of Vitruvian theory asserting the flexibility of the proportions of the canonical orders, was not explicitly stated by Palladio in the First Book of the Quattro Libri, although it was certainly implied. The only reference to optical correction appears in chapter XIII of book I, where Palladio reasserts exactly Vitruvius's proportional diminution or contractura of the upper diameter of the column in comparison to the lower diameter in order to compensate for the reductive effects of viewing from below. ${ }^{54}$ Palladio, however, was certainly aware of the role of optical corrections in Daniele Barbaro's architectural theory and probably shared the same ideas about the adaptations entailed by the site and visual conditions. For the Venetian patrician the adaptation by ancient architects of proportions to visual conditions and to necessity was the reason for there being so many different measurements in antique architecture. In his commentaries he attacks the arrogance of those

\footnotetext{
${ }^{52}$ Palladio 1570, 28: "Gli intercolumnij di due diametri e un quarto: e questa è la più bella, e commoda maniera d'intercolumnij: e da Vitruvio è detta Eustilos".

${ }^{53}$ Barozzi da Vignola 1562, address to the reader.

${ }^{54}$ Palladio 1570, Book I, 16.
} 
who slandered Vitruvius because of the lack of conformity between measurements taken from architectural ruins and those recommended by Vitruvius. Barbaro believed that those who thought in this way did not pay due attention to what Vitruvius himself had stated concerning the adaptation of his basic principles to the exigencies of a particular building, or to adaptations entailed by optical considerations and by the site. Barbaro insisted that Vitruvius had never intended his specifications for the orders to be regarded as unalterable rules. They were, on the contrary, guidelines that intelligent architects could modify, as Vitruvius himself recommended, according to visual conditions, site and necessity. Barbaro asserted also that essential skills, such as giudicio (judgement), destrezza (ability), discretione (choice) and sottigliezza (subtlety), were needed for the successful adjustment of proportions, and the necessary optical corrections. ${ }^{55}$

\section{Conclusion}

Palladio's attitude to Vitruvius leaves a margin wide enough to permit him to raise the ancient treatise to the level of an authority and to choose Vitruvius as "master and guide", while allowing him to remain to some extent independent and not simply an inflexible adherent of the Roman author. For Palladio, as for other Renaissance architects, archaeological evidence had more weight than the written words of Vitruvius and had precedence as an authority. The Vitruvian legacy in Palladio's canonical orders is to be traced mainly in Palladio's adoption of the module, and its internal division based on Vitruvius's numeri perfecti (6 x 10). Palladio adopted the picnostyle, systyle, eustyle, diastyle, and aerostyle intercolumniations of $1.5,2,2.25$, and 4 column diameters, and aligned himself with the diastyle intercolumniation of 2.75 diameters, as against 3 diameters recommended by Vitruvius. Palladio also followed Vitruvius for the layout of the details of the freestanding version of the Tuscan order, the baseless Doric, and in the rule of 1:7 and 1:9 (diameter to height) for the Tuscan and Ionic orders respectively. Palladio's canonical orders thus appear more Vitruvian than those of his predecessors, owing to his lifelong acquaintance with the classical treatise, and his intention to raise Vitruvius to the status of "master and guide".

Louis Cellauro

Collegium Helveticum (ETH Zurich und Universität Zurich)

lcellauro@hotmail.com

\footnotetext{
${ }^{55}$ Barbaro 1567, 133, 255 and 282.
} 


\section{BIBLIOGRAPHY}

Barbaro, D. 1556: I Dieci Libri dell'Architettura di $M$. Vitruvio, tradutti et commentati da Mons. Daniele Barbaro eletto Patriarca d'Aquileggia, (Francesco Marcolini), Venice.

Barbaro, D. 1567: I dieci libri dell'architettura di M. Vitruvio, tradutti et commentate da Mons. Daniele Barbaro eletto d'Aquileggia da lui riveduti et ora in più commoda forma ridotti (Francesco de' Franceschi), Venice.

Barkan, L. 2000: "The Heritage of Zeuxis: Painting, Rhetoric, and History", in Payne, A. Kuttner, A. and Smick, R. (eds), Antiquity and its Interpreters, Cambridge, 99-109.

Barozzi da Vignola, G. 1562: Regola delli cinque ordini, Rome.

Beltramini, G. and Burns, H. (eds) 2008: Palladio, London.

Boucher, B. 2000: "Nature and the Antique in the Work of Andrea Palladio", JSAH 59, 296-311.

Burns, H. 1984: "Raffaello e 'quell'antiqua architectura", in Frommel, C.L., Ray, S., Tafuri, M. (eds), Raffaello architetto, (exh. cat.), Milan, 381-407.

Burns, H. 1988: "Baldassare Peruzzi and sixteenth-century architectural theory", in Guillaume, J. (ed.), Les Traités d'Architecture de la Renaissance, Paris, 207-226.

Burns, H. 2008: “'Ornamenti' and ornamentation in Palladio's architecture", Pegasus 10, 37-84.

Cellauro, L. 2000: "Daniele Barbaro and his Venetian Editions of Vitruvius of 1556 and 1567", SVE N.S 40, 87134.

Cellauro, L. 2004: "Daniele Barbaro and Vitruvius: The Architectural Theory of a Venetian Humanist and Patron", PBSR 72, 293-329.

Cellauro, L. 2006: "Carlo Lodoli and Architecture: The Theory of an Eighteenth-Century Pioneer of Modernism", Architectura 36/1, 25-59.

Cellini, B. 1971: Opere, Giuseppe Guido Ferrero (ed.), Turin.

Ciapponi, L. 1960: "Il De architectura di Vitruvio nel primo Umanesimo", IMU 3, 59-99.

Clarke, G. 2002: "Vitruvian paradigms", PBSR 70, 317-344.

D'Evelyn, M.M. 2012: Venice and Vitruvius: Reading Venice with Daniele Barbaro and Andrea Palladio, New Haven and London.

Edlund-Berry, I. 2000: Lucy Shoe Meritt's Profiles of Roman and Etruscan Moldings, Austin, Texas.

Fontana, V. and Morachiello, P. 1975: Vitruvio e Raffaello. Il "De architectura" di Vitruvio nella traduzione di Fabio Calvo Ravennate, Rome.

Gualdo, P. 1959: "Vita di Andrea Palladio", in Zorzi, G. (ed.), SMSA 2, 93-104.

Günther, H. 1989: "Serlio e gli ordini architettonici", in Thoenes, C. (ed.), Sebastiano Serlio, Milan, 154-168.
Günther, H. 1990: "Palladio e gli ordini di colonne", in Chastel, A. and Cevese, R. (eds), Andrea Palladio, Milan, 182-197.

Hemsoll, D. 2015: "Palladio's Architectural Orders: From Practice to Theory", $A H$ 58, 1-54.

Hicks, P. and Hart, V. 1996: Serlio, On Architecture, New Haven and London.

Jones, M.W. 1991: "Designing the Roman Corinthian Capital”, PBSR LIX, 89-150.

Long, P. 1979: "The Vitruvian Commentary Tradition and Rational Architecture in the Sixteenth Century. A Study in the History of Ideas", PhD dissertation, Johns Hopkins University.

Mitrović, B. 1999: "Palladio's Theory of the Classical Orders in the First Book of I Quattro Libri dell'Architettura", $A H$ $42,110-140$.

Mitrović, B. 2002: "Palladio's Canonical Corinthian Entablature and the Archaeological Surveys in the Fourth Book of I Quattro Libri dell'Architettura", $A H$ 45, 113-127.

Morolli, G. 1985: Vetus Etruria: Il mito degli Etruschi nella letteratura architettonica, nell'arte e nella cultura da Vitruvio a Winckelmann, Florence.

Morsolin, B. 1894: Giangiorgio Trissino, monografia d'un gentiluomo letterato nel secolo XVI, Florence.

Pagliara, P.N. 1986: "Vitruvio da testo a canone", in Settis, S. (ed.), Memoria dell'Antico nell'Arte Italiana, Turin, 3-85.

Palladio, A. 1570: I Quattro Libri dell'Architettura (Domenico de' Franceschi), Venice.

Scamozzi, V. 1615: L'Idea dell'Architettura Universale, Venice.

Schofield, R. 2009: Vitruvius, On Architecture, London.

Serlio, S. 1537: Regole generali di architettura (Francesco Marcolini), Venice.

Summers, D. 1972: "Michelangelo on Architecture", $A B$ 54/2, 146-157.

Summers, D. 1981: Michelangelo and the Language of Art, Princeton.

Tavernor, R. 1991: Palladio and Palladianism, London.

Thoenes, C. 2002a: "Gli ordini architettonici: rinascita o invenzione", in Beyer A., Bredekamp H. and Cornelius Claussen P. (eds), Opus incertum, Munich, 199-213.

Thoenes, C. 2002b: "I precedenti della 'Regola"', in Tuttle, R.J. and Adorni, B. (eds), Jacopo Barozzi da Vignola, Milan, 352-361.

Zorzi, G. 1959: I disegni delle antichità di Andrea Palladio, Venice. 